\title{
Sixty Percent of Coös Youth Report Having a Mentor in Their Lives
}

\section{Benefits of Mentors for Adolescent Development}

A body of research illustrates a positive association between having a mentor and resilience in the face of adversity for adolescents. Specifically, mentors help to protect at-risk youth from a host of risk factors they face by modeling positive behavior, giving direct instruction, providing support, and channeling youth into constructive activities. ${ }^{1}$ Adolescents who have a mentor receive higher grades, display higher self-esteem, and report greater connectedness to their family and school compared to those who lack a mentor. ${ }^{2}$

Using the data from the Coös Youth Study, this fact sheet describes Coös youths' mentor relationships. To do so, we analyzed data from the Coös Youth Study collected in 2007 focusing on seventh and eleventh grade students from all public schools in Coös County.

\section{Frequency and Nature of Coös Youth-Mentor Relationships}

We asked Coös youth if there was an adult other than their parent or guardian with whom they share a special bond. Out of 635 students, 60.2 percent reported a mentor relationship. Of those with mentor relationships, 68.0 percent consisted of bonds with extended family members. Other mentor relationships mentioned included an adult friend (12.9 percent), school staff (11.8 percent), church and community members (4.6 percent), and 2.7 percent of mentors were undefined (see Figure 1).

\section{Key Findings}

- In 2007, a majority of Coös youth in seventh and eleventh grade (60.2 percent) report having a mentor.

- $\quad$ Sixty-eight percent of Coös youths' mentors are extended family members.

- $\quad$ Females are more likely than males to report a mentor relationship.
Figure 1. Type of Coös Youth-Mentor Relationships

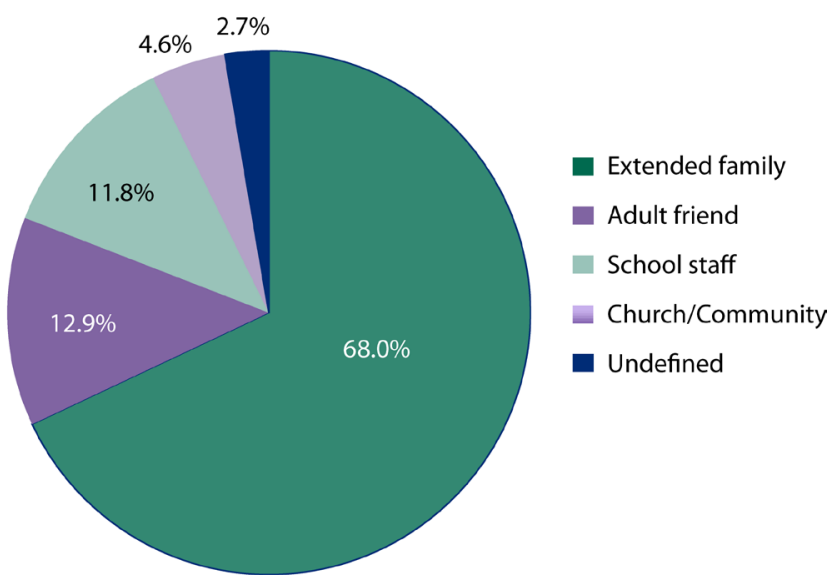

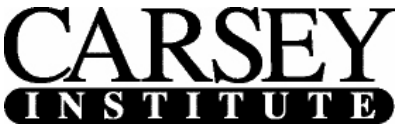

BUILDing KNOWLEDGE FOR Families ANd Communities
Huddleston Hall, 73 Main Street, Durham, NH 03824

(603) 862-2821 • www.carseyinstitute.unh.edu

This work was supported by the The Neil and Louise Tillotson Fund of the New Hampshire Charitable Foundation. 


\section{Do Mentor Relationships Differ by Gender and Grade Level?}

Seventy percent of female Coös youth reported a mentor relationship, while 49.0 percent of male Coös youth reported a mentor relationship. ${ }^{3}$ Our analysis comparing seventh and eleventh graders showed that they were equally likely to report having a mentor relationship.

\section{Are There Differences in Mentor Ex- perience by Parents' Marital Status?}

Many adolescents in mentoring programs come from singleparent homes (a requirement for some mentoring programs). ${ }^{4}$ Also, many adolescents develop natural mentoring relationships to satisfy emotional and social needs when they have unsatisfactory or challenging parental relationships. ${ }^{5}$ Our analysis, however, showed that Coös youths' reports of having an adult other than their parent/guardian with whom they share a special bond was unrelated to their parents' marital status. ${ }^{6}$

\section{Conclusion}

Research has consistently shown the benefits of mentor relationships for adolescent development. Coös youths' mentor relationships were predominately special bonds with extended family members, a finding that is consistent with research on national-level data showing that youth typically look to extended family for mentor relationships. ${ }^{7}$ Longevity of mentor relationships is important for gaining the benefits of a mentor relationship for adolescent development, ${ }^{8}$ and having a family member as a mentor may be linked to greater long-term mentoring relationships for adolescents.

Given the importance of mentors for adolescent development, there is a need in Coös County to provide opportunities to help males foster mentor relationships. Many mentoring programs have been developed at the national and local level due to their known benefits; however, few mentor programs for youth exist in Coös County. Efforts to continue and increase such programs would likely benefit Coös youth. Our analysis showed that mentor relationships do not vary in frequency in relation to parents' marital status. Mentoring relationships can play a crucial role in adolescents' lives, and efforts to strengthen the capacity for arranged and naturally occurring mentor relationships could be strengthened with local and broader support.

In this fact sheet, we described the frequency and characteristics of Coös youths mentor relationships. Future work with the Coös Youth Study will include examining the benefits of having a mentor relationship for Coös youths' well-being.
E N D N O T E S

1. D. L. DuBois and M. J. Karcher, Handbook of Youth Mentoring (CA: Sage Publications, 2005); N. M. Hurd, M. A. Zimmerman, and Y. Xue, "Negative Adult Influences and the Protective Effects of Role Models: A Study with Urban Adolescents," Journal of Youth and Adolescence, vol. 38 (2009): 777-789.

2. A. K. Yancey, J. M. Siegel, and K. L. McDaniel, "Role Models, Ethnic Identity, and Health-Risk Behaviors in Urban Adolescents," Archives of Pediatrics \& Adolescent Medicine, vol. 156 (2002): 55-61; J. E. Rhodes, J. B. Grossman, and N. L. Resch, "Agents of Change: Pathways Through Which Mentoring Relationships Influence Adolescents' Academic Adjustment, Child Development, vol. 71 (2000): 1662-1671.

3. A chi-squared test showed a significant gender difference in Coös youths' reports of having a mentor relationship.

4. J. B. Grossman and J. E. Rhodes, “The Test of Time: Predictors and Effects of Duration in Youth Mentoring Relationships," American Journal of Community Psychology, vol. 30 (2002): 199-219.

\section{Dubois and Karcher, Handbook of Youth Mentoring.}

6. Sixty-five percent of youth with divorced or separated parents, 62 percent of youths with widowed or never married parents, and 57 percent of Coös youth with a married parents report a mentor.

7. D. L. DuBois and N. Silverthorn, "Characteristics of Natural Mentoring Relationships and Adolescent Adjustment: Evidence from a National Study," Journal of Primary Prevention, vol. 26 (2005): 69-92.

8. Grossman and Rhodes, “The Test of Time."

\section{ABOUT THE AUTHORS}

Kent Scovill is a master of science candidate in family studies at the University of New Hampshire (kcn2@unh.edu).

Corinna Jenkins Tucker, $\mathrm{PhD}, \mathrm{CFLE}$, is a Carsey Institute faculty fellow and an associate professor in family studies at the University of New Hampshire (cjtucker@unh.edu).

\section{A C K N O W LED GEMEN T S}

This research is supported by the Neil and Louise Tillotson Fund of the New Hampshire Charitable Foundation, the Carsey Institute, and the National Science Foundation (\#155797). The Coös Youth Study Team thanks the students participating in this research project and the superintendents, principals, guidance counselors, teachers, and administrators who helped the team collect these data. Special thanks to fellow members of the Coös Youth Study research team, including Cesar Rebellon, Erin Hiley Sharp, and Karen Van Gundy, and project director, Eleanor Jaffee. Thank you to Amy Sterndale and Laurel Lloyd for their editorial assistance. 